\title{
Physiological Responses of Physalis angulata Plants to Water Deficit
}

\author{
Romeu da Silva Leite ${ }^{1}$, Marilza Neves do Nascimento ${ }^{2}$, Tamara Torres Tanan ${ }^{1}$, Cristiane Amaral da Silva Ramos ${ }^{1}$, \\ Lourival Palmeira Gonçalves Neto ${ }^{1} \&$ David Santana Guimarães ${ }^{1}$ \\ ${ }^{1}$ Postgraduate Program in Plant Genetic Resources, Universidade Estadual de Feira de Santana, Feira de Santana, \\ BA, Brazil \\ ${ }^{2}$ Department of Biological Sciences, Universidade Estadual de Feira de Santana, Feira de Santana, BA, Brazil \\ Correspondence: Romeu da Silva Leite, Postgraduate Program in Plant Genetic Resources, Universidade \\ Estadual de Feira de Santana, Av. Transnordestina, s/n, Labio, Novo Horizonte, Feira de Santana, CEP: 44036900, \\ BA, Brazil. E-mail: leiteromeu@hotmail.com
}

Received: June 28, 2018

Accepted: July 27, 2018

Online Published: September 15, 2018

doi:10.5539/jas.v10n10p287

URL: https://doi.org/10.5539/jas.v10n10p287

The research is financed by Brazilian Foundation for the Coordination of the Improvement of Higher Education Personnel (CAPES).

\begin{abstract}
It's known that drought affects crop growth, however, little is known about the physiological responses developed under these conditions by underexploited species, such as Physalis angulata. This study aimed at assessing the physiological responses of Physalis angulata plants after 40 days under different water availability $(100 \%, 80 \%, 60 \%, 40 \%$ and $20 \%$ of pot field capacity). In this research, the effects of the water deficit on the relative water content, water potential, gas exchange, sugars accumulation and activity of nitrate reductase were evaluated. Water relations were affected mainly in plants under severe water deficit, however, the variables remained stable when cultivated at sub-optimal levels of field capacity. Gas exchanges were also affected by water deficit, with reduction in carbon assimilation, internal carbon, stomatal conductance and transpiration, as well as increased leaf temperature and water use efficiency. Plants accumulated sugars as a mechanism of tolerance to severe water deficit, while nitrate reductase activity was reduced. P. angulata plants develop important strategies to tolerate water deficit, contributing to the establishment of crops under low water availability.
\end{abstract}

Keywords: drought, gas exchange, field capacity, Solanaceae, water relations

\section{Introduction}

Drought is a major abiotic stress limiting plant growth and productivity (Meng, Zhanga, Sua, Lia, \& Zhaoa, 2016), especially in arid and semi-arid regions. Drylands comprise approximately $40 \%$ of the terrestrial globe (Schlaepfer et al., 2017) and are characterized by great biodiversity, as well as providing plant genetic resources of regional interest and potential for exploitation, such as the species Physalis angulata (Solanaceae), of natural occurrence in the Brazilian semi-arid region.

Physalis is an American genus of interest for agriculture, since several species provide bittersweet fruits, characterized by inflated and persistent calyxes that cover the berries (Vargas-Ponce, Martínez, Tavares, \& Mares, 2016). The species Physalis angulata L. stands out for its medicinal use, in the treatment of several diseases, and for the presence of steroids called fisalinas (Guimarães et al., 2010; Oliveira, Gilbert, \& Villas Bôas, 2013; Sisley, Horna, Isern, Aranda-Ventura, \& Vallejo, 2017). Its fruits have aroused interest of farmers and consumers due to its sweet taste and high nutraceutical value (Lorenzi \& Matos, 2008). However, Physalis peruviana and Physalis ixocarpa are the most cultivated and marketed species, in most of the countries of Central and South America (Mokhtar, Swailam, \& Embaby, 2017; Morales-Contreras, Rosas-Flores, Contreras-Esquivel, Wicker, \& Morales-Castro, 2017), making P. angulata an alternative for insertion in growth of small fruits.

Numerous wild species and landraces that have commercial potential are of low economic value. The development of these underutilized or undervalued crops depends on factors related to the increase of quality, use and production potential for the market (Vargas-Ponce, Martínez, Tavares, \& Mares, 2016), usually 
associated with the establishment of cultivation techniques. In addition, in semi-arid conditions, the challenge is to select plants with tolerance to water deficit (Yu et al., 2013). In thus case, the first step is to evaluate the responses of these species to drought. One of the means of evaluation is through studies of physiological responses of the species under different field capacities.

Under abiotic stresses conditions, such as drought, some physiological processes are affected such as photosynthesis, protein synthesis and energy production (Flexas, Bota, Loreto, Cornic, \& Sharkey, 2004; Chaves, Flexas, \& Pinheiro, 2009). Water relations are also altered and evaluated mainly by the relative water content and water potential in the leaves, with some studies already reporting that for the genus Physalis (Souza \& Amorim, 2009; Segura-Monroy, Uribe-Vallejo, Ramirez-Godoy, \& Restrepo-Diaz, 2015). Water potential is used as a measure of the plant water status, since it regulates water transport through the membranes. For that, it is necessary that the plant presents a potential lower than that of the soil in order to water absorption to occur (Coêlho, 2014) and its maintenance to be closely related to the accumulation of organic solutes under water deficit conditions.

Sugars contents are highly sensitive to environmental stresses (Rosa et al., 2009) and their accumulation consists of a defense mechanism of the plant to dehydration, adjusting the ionic and osmotic balance and maintaining the turgor of the cells (Marijuan \& Bosch, 2013 ). Organic solutes accumulation under abiotic stresses conditions has been reported in several crops, such as cowpea (Sousa et al., 2015), pigeon pea (Monteiro, Cruz, Nardin, \& Santos, 2014), tomato (Ganbari \& Sayyari, 2018) and citrus (Zou, Wu, Huang, Ni, \& He, 2013; Vives-Peris, Candeas, \& Clementes, 2017). Other adaptive responses to water deficit may occur simultaneously, as changes in gas exchange and nitrate reductase enzyme activity, limiting nitrogen assimilation (Alguacil, Caravaca, Díaz-Vivancos, Hernández, \& Roldán, 2006).

Plants can quickly respond to water stress as a defense against water loss, with changes in stomatal conductance and reducing transpiration. However, this mechanism promotes an increase in leaf temperature and reduces gas exchange (Silva, Nogueira, Oliveira, \& Santos, 2008; Furlan, Llanes, Luna, \& Castro, 2018). It is important to note that there are few studies that evaluate the mechanisms employed by Physalis species in water deficit conditions, especially for $P$. angulata (Souza et al., 2013; Segura-Monroy, Uribe-Vallejo, Ramirez-Godoy, \& Restrepo-Diaz, 2015; Ozaslan et al., 2016). Thus, the characterization of the drought responses developed by the species may contribute to the cultivation techniques and future work on the selection of tolerant genotypes. In the light of the above, this work aimed to evaluate the physiological responses of $P$. angulata plants under different water availabilities.

\section{Materials and Methods}

\subsection{Obtaining Plant Material and Growth Conditions}

The experiment was carried out in a greenhouse, at the Horto Florestal Experimental Unity, University State of Feira de Santana, Feira de Santana, Brazil ( $12^{\circ} 14^{\prime} \mathrm{S}, 38^{\circ} 58^{\prime} \mathrm{W}, 258 \mathrm{~m}$ asl.), during the period from January to March 2018. Seedlings were produced from seeds obtained from matrices of Physalis angulata belonging to the research group. The seeds were planted in a polystyrene seedbed with commercial substrate. When the plants reached two pairs of true leaves, the transplant was performed for individual pots, spaced $0.6 \mathrm{~m}$ between rows $\mathrm{x}$ $0.3 \mathrm{~m}$ between plants. The soil was collected from the $0-20 \mathrm{~cm}$ depth layer, with the following physical and chemical characteristics, prior to fertigation, in $\mathrm{g} \mathrm{Kg}^{-1}$ : sand $=851$; clay $=90$; silt $=59$; in $\mathrm{g} \mathrm{dm}^{-3}: \mathrm{M} . \mathrm{W}$. $=16 ; \mathrm{P}=$ 16; in $\mathrm{mmol} \mathrm{dm}^{-3}: \mathrm{Al}^{3+}=1 ; \mathrm{K}=1.8 ; \mathrm{Ca}=11 ; \mathrm{Mg}=5 ;$ in $\mathrm{mg} \mathrm{dm}^{-3}: \mathrm{S}=6 ; \mathrm{B}=0.06 ; \mathrm{Cu}=0.8 ; \mathrm{Fe}=49 ; \mathrm{Mn}=2.1$ and $\mathrm{Zn}=2.6$.

\subsection{Soil Water Availability}

In order to simulate the effect of water availability, the maximum soil water storage capacity was determined from a test with three pots with perforations in its lower part. The pots of $10 \mathrm{dm}^{-3}$ were filled with $12.5 \mathrm{~kg}$ of air-dried soil and then saturated and suspended to drain water excess. After drainage (24 hours), the pots were weighed again and by weight difference the maximum water retention capacity of the soil in the pots was obtained according to Bonfim-Silva, Silva, Cabral, Kroth, and Rezende (2011). The evapotranspiration of each pot was determined based on weight, by using an electronic scale ( $5 \mathrm{~g}$ of precision).

Soil water availability was maintained at $80 \%$ of the maximum water retention capacity, up to 20 days after transplant (DAT). After that period the treatments were applied $(100 \%, 80 \%, 60 \%, 40 \%$ and $20 \%$ of water availability). The water replenishment was performed according to the gravimetric method, using daily weighing (twice a day), using an electronic scale and neglecting the daily increase in plants weight, restoring the water volume until the soil moisture reached the levels of water availability. 


\subsection{Fertigation and Cultural Dealings}

Plant fertigation was performed by monitoring the electrical conductivity of the saturation extract (Oliveira et al., 2016), using $50 \%$ of the ionic strength of the nutrient solution $(\mathrm{pH} 6.5)$ recommended for the hydroponic cultivation of $P$. angulata (Leite, Tanan, Nascimento, Oliveira, \& Abreu, 2017) to the pre-flowering stadium. During the cultivation, the vertical staking of the plants was performed and basal shoots and lateral branches were removed, allowing good light entry and aeration.

For the climatic characterization of the experimental conditions, daily measurements of temperature and air relative humidity were performed with digital thermohygrometer, installed at the canopy height of the culture inside the greenhouse (Figure 1a). The values for the vapor pressure deficit and solar radiation were collected from the automatic climatological station of the State University of Feira de Santana (Figure 1b).
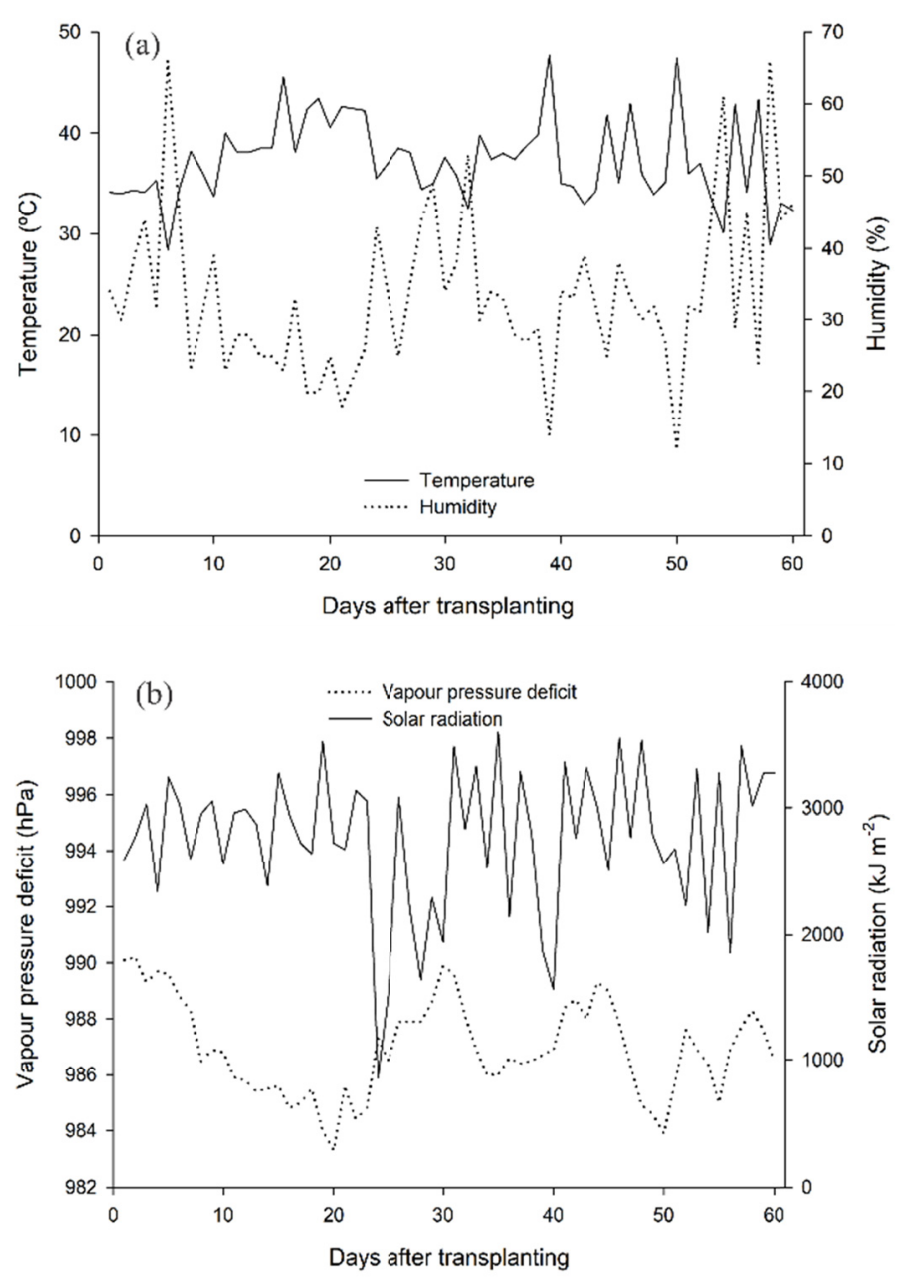

Figure 1. Climatic characterization during the experimental period

\subsection{Experimental Measurements}

Experimental measurements were assessed at 60 days after transplanting (DAT), totaling 40 days of cultivation under different percentages of pot field capacities.

\subsubsection{Relative Water Content and Water Potential}

The relative water content (RWC) was measured at 08:00 h, in fully expanded leaves located in the middle third of the plants. The determination of RWC was made based on the weight of eight leaf discs (Fresh Mass-FM, Turgid Mass-TM and Dry Mass-DM), according to the methodology of Weatherley (1950), using the following equation: 


$$
R W C=[(F M-D M) /(T M-D M)] \times 100
$$

The water potential $\left(\psi_{\mathrm{w} \text { foliar }}\right)$ was determined in the early morning, using a Scholander chamber (PMS 1000, PMS Instrument, Corvallis, USA), in leaves collected from the middle third of the plants.

\subsubsection{Gas Exchange}

The parameters of the gas exchange were checked using the InfraRed Gas Analyzer equipment (IRGA, model CIRAS-3, PPSystems, Amesbury, USA). Measurements were performed between 09:00 and 10:00 hours, using five plants per treatment, in completely developed leaves, recording three measurements for each plant for 60 seconds. The parameters obtained were: $\mathrm{CO}_{2}$ assimilation (A), transpiration rate (E), internal carbon concentration (Ci), stomatal conductance (gs), water use efficiency (WUE) and leaf temperature (Tleaf).

\subsubsection{Sugars Accumulation and Nitrate Reductase Activity}

Leaves located in the middle third of three plants of each treatment were collected for determination of sugars and enzymatic activity. The total soluble sugars were determined according to the methodology of Yemm and Willis (1954) and reducing sugars according to the procedures described by Miller (1959). Sucrose concentrations were determined by the difference between total soluble sugars and reducing sugars, using the factor 0.95 (Martim, 2003). The in vivo activity of nitrate reductase in leaves was determined according to the methodology proposed by Jaworski (1971) with adaptations.

\subsection{Statistical Analysis}

A completely randomized design was used with twelve repetitions per treatment, considering each pot an experimental unit. The data was subjected to the analysis of variance, through Tukey's test (5\% of significance) and regression by adjusting the equations of evaluated characteristics, as dependent of the water availability levels.

\section{Results and Discussion}

\subsection{Plant Water Relations}

A maintenance suboptimal soil water content alters the plants water relations (Puértolas, Larsen, Davies, \& Dodd, 2017), which was evidenced by the reduction in relative water content and water potential $\left(\psi_{\mathrm{w} \text { foliar }}\right)$ in plants grown with $20 \%$ of water availability (Figure 2). The relative water content in the leaf remained constant up to $40 \%$ of the field capacity, indicating that even under conditions of moderate water deficit, the species can keep its cells hydrated, despite differences in gas exchange (Figure 2a). However, it is worth mentioning that the plants were able to rehydrate at night, even when there were low levels of water in the soil, being an important tolerance characteristic.

The low soil water availability reduced the water potential of the plants (Figure 2b), with no statistical difference, up to $40 \%$ of the field capacity, differing from the plants grown in $20 \%$ of the field capacity, which presented an average $\psi_{\mathrm{w} \text { foliar }}$ of $-1.33 \mathrm{MPa}$. The observed reduction in leaf water potential may be related to the sugars accumulation in leaves, which together with other physiological mechanisms, such as stomatal closure and reduced transpiration, contribute to the maintenance of tissue hydration. Other species also showed reduced water potential when under conditions of low water availability (Ronchi et al., 2015, Mota \& Cano, 2016).

\subsection{Leaf Gas Exchange}

An adjustment to the increasing linear regression model was observed for $\mathrm{CO}_{2}$ assimilation and internal carbon concentration, as water availability for plants increased. The $\mathrm{CO}_{2}$ assimilation rate decreased by $41.06 \%$ when compared to plants growth with $100 \%$ and $20 \%$ of field capacity (Figure $3 \mathrm{a}$ ). The effects of reducing water availability on the photosynthetic rate were reported in several studies (Rahmati et al., 2015; X. Wang, L. Wang, \& Shangguan, 2016; Pazzagli, Weiner, \& Liu, 2016). The used Physalis angulata plants showed little tolerance to low levels of water in the soil in relation to the gas exchange, with severely affected carbon assimilation.

The highest internal carbon concentration (Ci) was observed for $100 \%$ of the field capacity $\left(271.6 \mu \mathrm{mol} \mathrm{mol}^{-1}\right)$, with a decrease of $31.36 \%$ parallel to a reduction of water availability in $20 \%$ (Figure 3b). Silva et al. (2015) observed similar behavior in plants of the eggplant Ciça variety, with higher internal carbon values in the largest used irrigation blade. The reduction in photosynthesis is related to the stomatal closure and the consequent reduction of $\mathrm{CO}_{2}$ flow to the carboxylation site (Bosco, Oliveira, Hernandez, \& Lacerda, 2009), both evidenced by the lower stomatal conductance observed in $20 \%$ of the field capacity and by biochemical limitations (Silva et al., 2012) under water deficit conditions. 


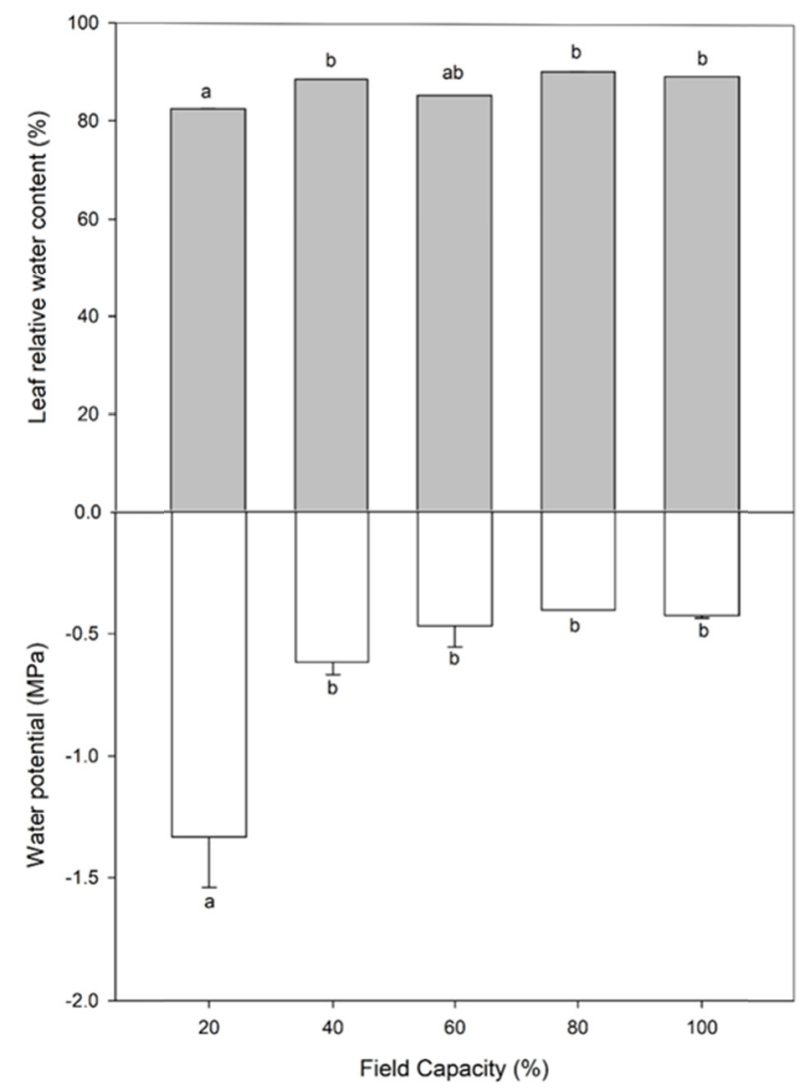

Figure 2. Water relations in Physalis angulata plants: relative water content in leaves and water potential. Values sharing the same letters are not significantly different at $5 \%$ significance level

The stomatal conductance (gs) was negatively influenced by the reduction of water availability, and the data was adjusted to the linear regression model (Figure 3c). Stomatal closure is one of the plant defense lines against the lack of water (Taiz \& Zeiger, 2009), while gs is a key factor that determines other physiological variables, such as the liquid photosynthesis rate, and therefore, the carbon metabolism of the plant (Urban, Ingwers, McGuire, \& Teskey, 2017). The highest value for stomatal conductance $\left(253.9 \mathrm{mmol} \mathrm{H}_{2} \mathrm{O} \mathrm{m}^{-1} \mathrm{~s}^{-1}\right)$ was observed in plants with the highest water availability, while gs was reduced in $73.37 \%$ in the plants grown at $20 \%$ of field capacity. The reduction of gs in deficit irrigation conditions was also observed in other solanaceous crops, such as eggplant (Silva et al., 2015) and tomato (Pazzagli et al., 2016). 

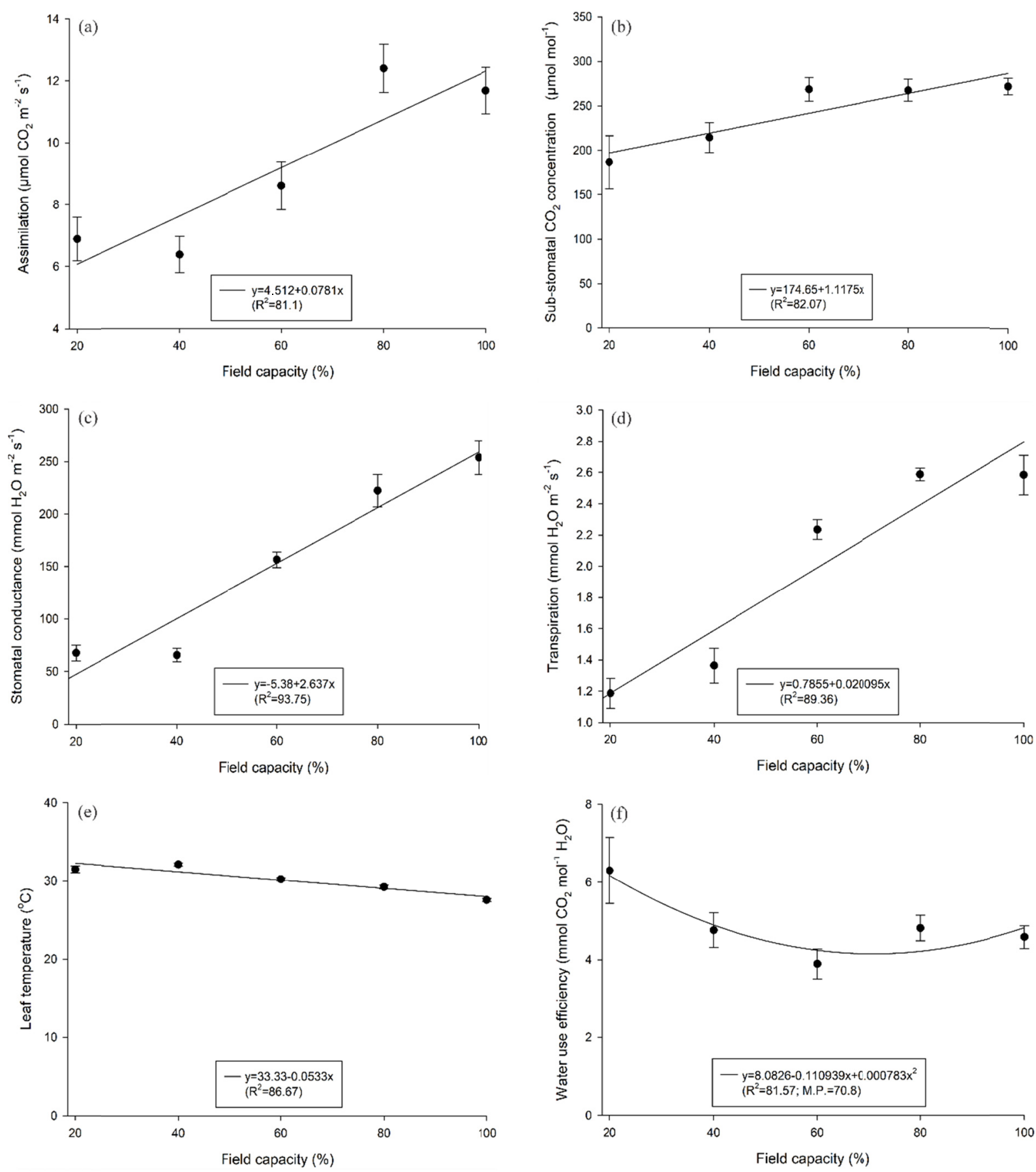

Figure 3. Gas exchange in Physalis plants: (a) assimilation; (b) sub-stomatal $\mathrm{CO}_{2}$ concentration; (c) stomatal conductance; (d) transpiration; (e) leaf temperature; (f) water use efficiency

P. angulata plants cultivated at maximum field capacity showed high transpiration rates (E) $\left(2.58 \mathrm{mmol} \mathrm{H}_{2} \mathrm{O} \mathrm{m}^{-2}\right.$ $\mathrm{s}^{-1}$ ), being reduced as soil water became scarce, with an $\mathrm{E}$ value of $1.18 \mathrm{mmol} \mathrm{H}_{2} \mathrm{O} \mathrm{m}^{-2} \mathrm{~s}^{-1}$ at the lowest available water availability (Figure 3d). The reduction of transpiration, due to changes in stomatal opening as a response to low soil water stresses, influenced the increase in leaf temperature. Plants grown in $20 \%$ of field capacity showed leaf temperature with $3.89^{\circ} \mathrm{C}$ higher than well-hydrated plants at $100 \%$ of field capacity (Figure 3e).

The plants cultivated at the lowest water availability were able to maintain high water use efficiency (WUE), being an important characteristic of adaptation to water deficit conditions (Figure 3f), for it expresses the relation between the assimilation rate of $\mathrm{CO}_{2}$ and transpiration, relating the amount of carbon that is fixed by the plant per unit of transpirated water (Campos, Lima, Azevedo, Nascimento, \& Silva, 2016). Cultivation at $20 \%$ of field 
capacity resulted in higher WUE $\left(6.30 \mathrm{mmol} \mathrm{CO}_{2} \mathrm{~mol}^{-1} \mathrm{H}_{2} \mathrm{O}\right)$. Comparatively, this result was $27.46 \%$ higher than those obtained in plants with greater water availability, and other studies also reported an increase in the WUE under abiotic stress conditions (Bota,Tomás, Flexas, Medrano, \& Escalona, 2015; Bacha et al., 2016).

\subsection{Sugars Accumulation and Nitrate Reductase Activity}

The contents of total soluble sugars, reducing sugars and sucrose in the leaves of $P$. angulata, were higher with the reduction of the amount of water in the soil (Figures $4 a, 4 b$ and $4 c$ ). The accumulation of these solutes plays an important role in the tolerance to abiotic stresses (Ma et al., 2017) and, in comparison to this work, studies reported increases in sugar levels under conditions of water deficit for other species (Silva et al., 2012; Kuang, Xu, Zhang, Hou, \& Shen, 2017; Salehi, Tasdighi, \& Gholamhoseini, 2016).

The contents of total soluble sugars $\left(15.39 \mathrm{mg} \mathrm{g} \mathrm{FW}^{-1}\right)$, reducing sugars $\left(5.66 \mathrm{mg} \mathrm{g} \mathrm{FW}^{-1}\right)$ and sucrose $(9.69 \mathrm{mg}$ $\left.\mathrm{g} \mathrm{FW}^{-1}\right)$ in plants grown at $20 \%$ of the field capacity are associated with the lowest water potential $(-1.33 \mathrm{MPa})$, demonstrating that the accumulation of these sugars promoted the osmotic adjustment in P. angulata. This is a characteristic of great importance for plants with potential for exploration, since osmotic adjustment helps to protect against dehydration, reducing the water potential of the plant in relation to the soil and allowing the root to capture and prevent the loss of water (Coêlho, 2014), thus reducing crop losses under drought conditions.
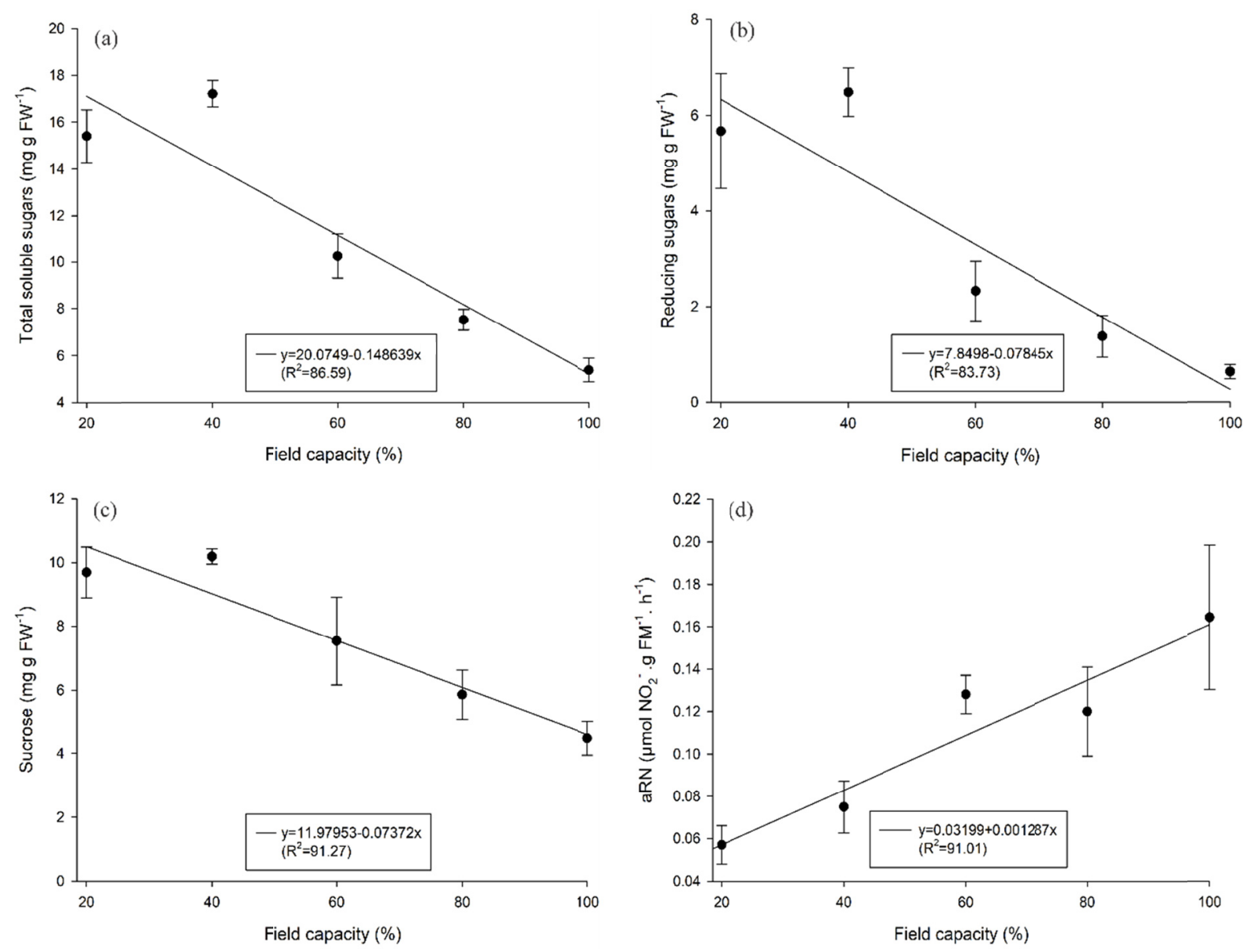

Figure 4. Sugars accumulation and enzymatic activity in Physalis angulata: (a) total soluble sugars; (b) reducing sugars; (c) sucrose; (d) nitrate reductase activity

Water deficit triggered a linear reduction $\left(\mathrm{R}^{2}=91.01\right)$ of nitrate reductase enzymatic activity $(\mathrm{NR})$ (Figure $\left.4 \mathrm{~d}\right)$ in $P$. angulata plants. The lower activity of the NR may be associated with the reduction of photosynthesis, since $\mathrm{NR}$ is dependent on the NADH generated in the photochemical stage. In addition to this, under drought conditions there is a lower content of available $\mathrm{NO}_{3}^{-}(\mathrm{Xu} \& \mathrm{Yu}, 2006)$, since stomatal closure, as a line of defense to water loss, reduces the translocation flow through the xylem and consequently the transport of nitrate 
from roots to leaves, reducing leaf NR activity (Konishi \& Yanagisawa, 2011). Reduction in NR activity in water deficit conditions was also observed in other studies (Meng et al., 2015; Zahoor, Zhao, Abid, Dong, \& Zhou, 2017).

\section{Conclusions}

The Physalis angulata plants evaluated in this study showed important physiological and biochemical mechanisms of tolerance to water deficit. Under conditions of low water availability, the tolerance of the species is evidenced by the increase in water use efficiency, as well as the osmotic adjustment promoted by sugars accumulation. These responses are important for establishing the species' crops in environments with limited water availability, as in semi-arid regions.

\section{Acknowledgements}

We thank the Brazilian Foundation for the Coordination of the Improvement of Higher Education Personnel (CAPES) for the financial support for this work.

\section{References}

Alguacil, M., Caravaca, F., Díaz-Vivancos, P., Hernández, J. A., \& Roldán, A. (2006). Effect of arbuscular mycorrhizae and induced drought stress on antioxidant enzyme and nitrate reductase activities in Juniperus oxycedrus L. grown in a composted sewage sludge-amended semi-arid soil. Plant Soil, 279, 209-218. https://doi.org/10.1007/s11104-005-1238-3

Bacha, H., Tekaya, M., Drine, S., Guasmi, F., Touil, L., Enneb, H., \& Ferchichi, A. (2016). Impact of salt stress on morpho-physiological and biochemical parameters of Solanum lycopersicum cv. Microtom leaves. South African Journal of Botany, 108, 364-369. https://doi.org/10.1016/j.sajb.2016.08.018

Bonfim-Silva, E. M., Silva, T. J. A., Cabral, C. E. A., Kroth, B. E., \& Rezende, D. (2011). Desenvolvimento inicial de gramíneas submetidas ao estresse hídrico. Revista Caatinga, 24(2), 180-186.

Bosco, M. R. O., Oliveira, A. B., Hernandez, F. F. F., \& Lacerda, C. F. (2009). Efeito do NaCl sobre o crescimento, fotossíntese e relações hídricas de plantas de berinjela. Revista Ceres, 56(03), $296-302$.

Bota, J., Tomás, M., Flexas, J., Medrano, H., \& Escalona, J. M. (2015). Differences among grapevine cultivars in their stomatal behavior and water use efficiency under progressive water stress. Agricultural Water Management, 164, 91-99. https://doi.org/10.1016/j.agwat.2015.07.016

Campos, A. R. F., Lima, R. L. S., Azevedo, C. A. V., Nascimento, R., \& Silva, S. S. (2016). Physiological attributes of jatropha under different planting densities and nitrogen doses. Revista Brasileira de Engenharia Agrícola e Ambiental, 20(12), 1112-1117. https://doi.org//10.1590/1807-1929/agriambi.v20n12 p1112-1117

Chaves, M. M., Flexas, J., \& Pinheiro, C. (2009). Photosynthesis under drought and salt stress: Regulation mechanisms from whole plant to cell. Annals of Botany, 103, 551-560. https://doi.org/10.1093/aob/mcn125

Coêlho, M. R. V. (2014). Alterações fisiológicas e metabólicas em Hyptis fruticosa Salzm. ex. Beth e Ocimum gratissimum L. sob diferentes regimes hídricos (Master's thesis, Universidade Estadual de Feira de Santana, Feira de Santana, Brazil). Retrieved from http://tede2.uefs.br:8080/handle/tede/111

Flexas, J., Bota J., Loreto, F., Cornig, G., \& Sharkey, T. D. (2004). Diffusive and metabolic limitations to photosynthesis under drought and salinity in C3 plants. Plant Biology, 6, 269-279. https://doi.org/10.1055/ s-2004-820867

Furlan, A., Llanes, A., Luna, A., \& Castro, S. (2012). Physiological and biochemical responses to drought stress and subsequent rehydration in the symbiotic association Peanut-Bradyrhizobium sp. ISRN Agronomy, 2012, 8. https://doi.org/10.5402/2012/318083

Ganbari, F., \& Sayyari, M. (2018). Controlled drought stress affects the chilling-hardening capacity of tomato seedlings as indicated by changes in phenol metabolisms, antioxidant enzymes activity, osmolytes concentration and abscisic acid accumulation. Scientia Horticulturae, 229, 167-174. https://doi.org/10.1016/ j.scienta.2017.10.009

Guimarães, E. T., Lima, M. S., Santos, L. A., Ribeiro, I. M., Tomassini, T. B. C., ... Soares, M. B. P. (2010). Effects of seco-steroids purified from Physalis angulata L., Solanaceae, on the viability of Leishmania sp. Revista Brasileira de Farmacognosia, 20(6), 945-949. https://doi.org/10.1590/S0102-695X2010005000036 
Jaworski, E. G. (1971). Nitrate reductase assay in intact plant tissues. Biochemical and Biophysical Research Communications, 43, 1274-1279. https://doi.org/10.1016/S0006-291X(71)80010-4

Konishi, M., \& Yanagisawa, S. (2011). The regulatory region controlling the nitrate-responsive expression of a nitrate reductase gene, NIA1, in Arabidopsis. Plant and Cell Physiology, 52(5), 824-836. https://doi.org/ $10.1093 / \mathrm{pcp} / \mathrm{pcr} 033$

Kuang, Y. W., Xu, Y. M., Zhang, L. L., Hou, E. Q., \& Shen, W. J. (2017). Dominant trees in a subtropical forest respond to drought mainly via adjusting tissue soluble sugar and proline content. Frontiers in Plant Science, 8, 802. https://doi.org/10.3389/fpls.2017.00802

Leite, R. S., Tanan, T. T., Nascimento, M. N., Oliveira, L. M., \& Abreu, P. A. S. (2017). Hydroponic cultivation of Physalis angulata L.: Growth and production under nitrogen doses. Pesquisa Agropecuária Tropical, 47, 145-151. https://doi.org/10.1590/1983-40632016v4744652

Lorenzi, H., \& Matos, F. J. A. (2008). Plantas medicinais no Brasil: Nativas e exóticas cultivadas (2nd ed.). Nova Odessa, SP: Instituto Plantarum.

Ma, Q. J., Sun, M. H., Lu, J., Liu, Y. J., Hu, D. G., \& Hao, Y. J. (2017). Transcription factor AREB2 is involved in soluble sugar accumulation by activating sugar transporter and amylase genes. Plant Physiology, 174(4), 2348-2362. https://doi.org/10.1104/pp.17.00502

Marijuan, M. P., \& Bosch, S. M. (2013). Ecophysiology of invasive plants: Osmotic adjustment and antioxidants. Trends in Plant Science, 18, 660-666. https://doi.org/10.1016/j.tplants.2013.08.006

Martim, S. A. (2003). Pulverização do cafeeiro com açúcar: potencial de uso em mudas submetidas à deficiência hídrica e na recuperação de plantas atingidas por Glyphosate (Master's thesis, Universidade Federal de Lavras, Lavras, Brazil). Retrieved from http://www.sbicafe.ufv.br/handle/123456789/113

Meng, S., Zhanga, C., Sua, L., Lia, Y., \& Zhaoa, Z. (2016). Nitrogen uptake and metabolism of Populus simonii in response to PEG-induced drought stress. Environmental and Experimental Botany, 123, 78-87. https://doi.org/10.1016/j.envexpbot.2015.11.005

Miller, G. L. (1959). Use of dinitrosalicylic acid reagent for determination of reducing sugar. Analytical Biochemistry, 31, 426-428. https://doi.org/10.1021/ac60147a030

Mokhtar, S. M., Swailam, H. M., \& Embaby, H. E.-S. (2017). Physicochemical properties, nutritional value and techno-funnctional properties of goldenberry (Physalis peruviana) waste powder. Food Chemistry, $248,7$. https://doi.org/10.1016/j.foodchem.2017.11.117

Monteiro, J. G., Cruz, F. J. R., Nardin, M. B. N., \& Santos, D. M. M. (2014). Crescimento e conteúdo de prolina em plântulas de guandu submetidas a estresse osmótico e à putrescina exógena. Pesquisa Agropecuária Brasileira, 49(1), 18-25. https://doi.org/10.1590/S0100-204X2014000100003

Morales-Contreras, B. E., Rosas-Flores, W., Contreras-Esquivel, J. C., Wicker, L., \& Morales-Castro, J. (2018). Pectin from husk tomato (Physalis ixocarpa brot.): rheological behavior at different extraction conditions. Carbohydrate Polymers, 179, 282-289. https://doi.org/10.1016/j.carbpol.2017.09.097

Mota, C. S., \& Cano, M. A. O. (2016). Matter accumulation and photosynthetic responses of macaw palm to cyclical drought. Revista Caatinga, 29(4), 850-858. https://doi.org/10.1590/1983-21252016v29n409rc

Oliveira, F. A., Duarte, S. N., Medeiros, J. F., Oliveira, M. K. T., Silva, R. C. P., \& Souza, M. S. (2016). Eficiência da fertirrigação nitrogenada e potássica na produção de pimentão cultivado em ambiente protegido. Amazonian Journal of Agricultural and Environmental Sciences, 59(3), 293-301. https://doi.org/ $10.4322 /$ rca. 2560

Oliveira, L. F. G., Gilbert, B., \& Villas Bôas, G. K. (2013). Oportunidades para inovação no tratamento da leishmaniose usando o potencial das plantas e produtos naturais como fontes de novos fármacos. Revista Fitos, 8, 33-42.

Ozaslan, C., Farooq, S., Onen, H., Bukun, B., Ozcan, S., \& Gunal, H. (2016). Invasion potential of two tropical physalis species in arid and semi-arid climates: Effect of water-salinity stress and soiltypes on growth and fecundity. PLoS ONE, 11(10), e0164369. https://doi.org/10.1371/journal.pone.0164369

Pazzagli, P. T., Weiner, J., \& Liu, F. (2016). Effects of $\mathrm{CO}_{2}$ elevation and irrigation regimes on leaf gas exchange, plant water relations, and water use efficiency of two tomato cultivars. Agricultural Water Management, 169, 6-33. https://doi.org/10.1016/j.agwat.2016.02.015 
Puértolas, J., Larsen, E. K., Davies, W. J., \& Dodd, I. C. (2017). Applying 'drought' to potted plants by maintaining suboptimal soil moisture improves plant water relations. Journal of Experimental Botany, 68 , 2413-2424. https://doi.org/10.1093/jxb/erx116

Rahmati, M., Davarynejad, G. H., Génard, M., Bannayan, M., Azizi, M., \& Vercambre, G. (2015). Peach water relations, gas exchange, growth and shoot mortality under water deficit in semi-arid weather conditions. PLoS ONE, 10(4), e0120246. https://doi.org/10.1371/journal.pone.0120246

Ronchi, C. P., Araújo, F. C., Almeida, W. L., Silva, M. A. A., Magalhães, C. E. O., Oliveira, L. B., \& Drumond, L. C. D. (2015). Respostas ecofisiológicas de cafeeiros submetidos ao deficit hídrico para concentração da florada no Cerrado de Minas Gerais. Pesquisa Agropecuária Brasileira, 50(1), 24-32. https://doi.org/ 10.1590/S0100-204X2015000100003

Rosa, M., Prado, C., Podazza, G., Interdonato, R., Gonzalez, J. A., Hilal, M., \& Prado, F. E. (2009). Soluble sugars-Metabolism, sensing and abiotic stress. Plant Signaling \& Behavior, 4, 388-393. https://doi.org/ 10.4161/psb.4.5.8294

Salehi, A., Tasdighi, H., \& Gholamhoseini, M. (2016). Evaluation of proline, chlorophyll, soluble sugar content and uptake of nutrients in the German chamomile (Matricaria chamomilla L.) under drought stress and organic fertilizer treatments. Asian Pacific Journal of Tropical Biomedicine, 6(10), 886-891. https://doi.org/ 10.1016/j.apjtb.2016.08.009

Schlaepfer, D. R., Bradford, J. B., Lauenroth, W. K., Munson, S. M., Tietjen, B., Hall, S. A., ... Jamiyansharav, K. (2017). Climate change reduces extent of temperate drylands and intensifes drought in deep soils. Nature Communication, 8(14196). https://doi.org/10.1038/ncomms 14196

Segura-Monroy, S., Uribe-Vallejo, A., Ramirez-Godoy, A., \& Restrepo-Diaz, H. (2015). Effect of kaolin application on growth, water use efficiency, and leaf epidermis characteristics of Physalis peruviana $\mathrm{L}$. seedlings under two irrigation regimes. Journal of Agricultural Science and Technology, 17, 1585-1596.

Silva, E. N., Ribeiro, R. V., Ferreira-Silva, S. L., Vieira, S. A., Ponte, L. F. A., \& Silveira, J. A. G. (2012). Coordinate changes in photosynthesis, sugar accumulation and antioxidative enzymes improve the performance of Jatropha curcas plants under drought stress. Biomass and Bioenergy, 45, 270-279. https://doi.org/10.1016/j.biombioe.2012.06.009

Silva, F. G., Dutra, W. F., Dutra, A. F., Oliveira, I. M., Filgueiras, L. M. B., \& Melo, A. S. (2015). Trocas gasosas e fluorescência da clorofila em plantas de berinjela sob lâminas de irrigação. Revista Brasileira de Engenharia Agrícola e Ambiental, 19(10), 946-952. https://doi.org/10.1590/1807-1929/agriambi.v19n10 p946-952

Silva, M. A. V., Nogueira, R. J. M. C., Oliveira, A. F. M., \& Santos, V. F. (2008). Resposta estomática e produção de matéria seca em plantas jovens de aroeira submetidas a diferentes regimes hídricos. Revista Árvore, 32(2), 335-344. https://doi.org/10.1590/S0100-67622008000200016

Silveira, N. M., Hancock, J. T., Frungillo, L., Siasou, E., Marcos, F. C. C., Salgado, I., ... Ribeiro, R. V. (2017) Evidence towards the involvement of nitric oxide in drought tolerance of sugarcane. Plant Physiology et Biochemistry, 15, 354-359. https://doi.org/10.1016/j.plaphy.2017.04.011

Sisley, G. M. M., Horna, F. Y. M., Isern, R. F., Aranda-Ventura, J., Vallejo, V. J. (2017). Actividad inmunoestimulante del extracto acuoso liofilizado de la planta entera de Physalis angulata L. en ratas albinas cepa Holtzman. Revista Peruana de Medicina Integrativa, 2(1), 38-46. https://doi.org/10.26722/ rpmi.2017.21.43

Sousa, C. C. M., Pedrosa, E. M. R., Rolim, M. M., Oliveira Filho, R. A., Souza, M. A. L. M., \& Pereira Filho, J. V. (2015). Crescimento e respostas enzimáticas do feijoeiro caupi sob estresse hídrico e nematoide de galhas. Revista Brasileira de Engenharia Agricola e Ambiental, 19(2), 113-118. https://doi.org/10.1590/ 1807-1929/agriambi.v19n2p113-118

Souza, M. O., Pelacani, C. R., Soares, M., Mazzei, J. L., Ribeiro, I. M., Rodrigues, C. P., \& Tomassini, T. C. B. (2013). Osmotic priming effects on emergence of Physalis angulata and the influence of abiotic stresses on physalin content. South African Journal of Botany, 88, 191-197. https://doi.org/10.1016/j.sajb.2013.07.025

Souza, N. K. R., \& Amorim, S. M. C. (2009) Crescimento e desenvolvimento de Physalis angulata Lineu submetida ao déficit hídrico. Revista Acadêmica de Ciências Agrárias e Ambientais, 7(1), 65-72. https://doi.org/10.7213/cienciaanimal.v7i1.8942 
Taiz, L., \& Zeiger, E. (2009). Fisiologia vegetal (4th ed.). Porto Alegre, RS: Artmed.

Urban, J., Ingwers, M. W., Mcguire, M. A., \& Teskey, R. O. (2017). Increase in leaf temperature opens stomata and decouples net photosynthesis from stomatal conductance in Pinus taeda and Populus deltoides $\mathrm{x}$ nigra. Journal of Experimental Botany, 68(7), 1757-1767. https://doi.org/10.1093/jxb/erx052

Vargas-Ponce, O., Martínez, J. S., Tavares, M. P. Z., \& Mares, L. E. V. (2016). Traditional management of a small-scale crop of Physalis angulata in Western Mexico. Genetic Resources and Crop Evolution, 63, 1383-1395. https://doi.org/10.1007/s10722-015-0326-3

Vives-Peris, V., Candeas, A. G., \& Clementes, R. M. P. (2017). Citrus plants exude proline and phytohormones under abiotic stress conditions. Plant Cell Reports, 36(12), 1971-1984. https://doi.org/10.1007/s00299017-2214-0

Wang, X., Wang, L., \& Shangguan, Z. (2016). Leaf gas exchange and fluorescence of two winter wheat varieties in response to drought stress and nitrogen supply. PLOS ONE, 11(11), e0165733. https://doi.org/10.1371/ journal.pone. 0165733

Weatherley, P. E. (1950). Studies in the water relations of the cotton plant I. The field measurement of water deficits in leaves. New Phytologist, 49, 81-87. https://doi.org/10.1111/j.1469-8137.1950.tb05146.x

$\mathrm{Xu}, \mathrm{Z} .$, \& Yu, Z. (2006). Nitrogen metabolism in flag leaf and grain of wheat in response to irrigation regimes. Journal Plant Nutrition and Soil Science, 169, 118-126. https://doi.org/10.1002/jpln.200420418

Yemm, E. W., \& Willis, A. J. (1954). The estimation of carbohydrates in plant extracts by anthrone. The Biochemical Journal, 57, 508-514. https://doi.org/10.1042/bj0570508

Yu, L., Chen, X., Wang, Z., Wang, S., Wang, Y, Zhu, Q, ... Xiang, C. (2013). Arabidopsis enhanced drought tolerance1/HOMEODOMAIN GLABROUS11 confers drought tolerance in transgenic rice without yield penalty. Plant Physiology, 162(3), 1378-1391. https://doi.org/10.1104/pp.113.217596

Zahoor, R., Zhao, W., Abid, M., Dong, H., \& Zhou, Z. (2017). Potassium application regulates nitrogen metabolism and osmotic adjustment in cotton (Gossypium hirsutum L.) functional leaf under drought stress. Journal of Plant Physiology, 215, 30-38. https://doi.org/10.1016/j.jplph.2017.05.001

Zou, Y. N., Wu, Q. S., Huang, Y. M., Ni, Q. D., \& He, X. H. (2013). Mycorrhizal-mediated lower proline accumulation in Poncirus trifoliata under water deficit derives from the integration of inhibition of proline synthesis with increase of proline degradation. PLOS ONE, 8(11). https://doi.org/10.1371/journal.pone. 0080568

\section{Copyrights}

Copyright for this article is retained by the author (s), with first publication rights granted to the journal.

This is an open-access article distributed under the terms and conditions of the Creative Commons Attribution license (http://creativecommons.org/licenses/by/4.0/). 